Mr. John Lawrance, senior, of Brighton; Mr. Bottomley, of Croydon, Mr. Macilwain, \&c., \&c., to give evidence before the parliamentary committee, as to what the wishes of the great body of the surgeons of England are.

The first determination I conceive would be, that they decidedly object to be enrolled in a bastard-bred institution; that they require no third grade; that they consider, instead of there being a third institution, that the entire profession ought rather to be concentrated into one. "A third grade," as the late Dr. Lynch very properly defined, in one of his speeches at the Hanover-square Rooms, "would be a retrograde movement; they would become, not apothecaries, but medical hermaphrodites-neither surgeon nor physician, neither fish nor flesh, an amphibious species, a mulish crossfor which ingenuity could not devise a complimentary cog. nomen, nor an appropriate appellation."

Secondly. That the late charter granted to the College of Surgeons should be repealed.

Thirdly. That a new one be granted, to be confirmed by act of parliament, giving the present council of the college power to elect six examiners from the present examiners of the Apothecaries' Company, and six other qualified men from some other source to examine in medicine, materia medica, chemistry, botany, midwifery, \&c.

Fourthly. That the Act of 1815 should be repealed; and that the licentiates of the Hall should be enrolled in the College of Surgeons upon payment of the stamp duty and a small sum, say five pounds.

Fifthly. That all members of the college of ten or twelve years' standing, of unblemished character, should attain the fellowship without fee or examination.

Sixthly. That the colleges of surgeons in Ireland and Scotland be constituted exactly like that of England; and the members thereof allowed to practice in any part of her Majesty's dominions.

Seventhly. That every man before he could be admitted for an examination at the College of Physicians in either country, must have passed his general examination at one of the colleges of surgeons at least seven years previously.

The above, I believe, are pretty nearly the views entertained by yourself, and are somewhat consonant with the evidence given by Mr. Guthrie before the parliamentary committee.

Suppose there were an advertisement published in the Times, calling a meeting for Saturday, the 17th of June, at Exeter Hall, and requesting all those who are favourable to the advertisement to send postage-stamps to the amount of $2 s .6 d$. to pay for the Hall, which, I believe, is $£ 15$ or $£ 20$,- the said postage-stamps to be sent to the Editor of THE LANCET' (indeed, 500 members, each sending one shilling's worth of stamps would more than pay all costs) -and whatever overplus there might be, if any, should be given to the widow of the late Dr. Lynch, whom, I believe, from his untimely death, was left very ill-provided for. If these few hints, hastily thrown together, are worthy a place in Trz LANCET, you would oblige me by inserting the same.-I am, Sir, your obedient servant,

June, 1848 .

H. H. R.

** Our correspondent's letter is duly authenticated.ED. L.

\section{MEETING OF MEMBERS OF THE COLLEGE OF SURGEONS AT COLCHESTER. To the Editor of The Lancet.}

Sir,--It may perhaps aid our cause in some degree if you could notice, in your next number of THE LANCET, that a public meeting of the members of the College of Surgeons residing in the county of Essex was convened for Friday, June 9 th, at Colchester, for taking into consideration the odious provisions of the charter of 1843 .

It is most desirable that meetings of this kind should take place, and delegates be sent to the parliamentary committee without delay, praying for an abrogation of the present charter, \&c. The members of our profession are deeply indebted to you for your unceasing exertions in their behalf, and as an individual $I$ beg to offer you my best thanks.

Witham, Essex, June 6th, 1848. I am, Sir, yours truly,

The following remarks constitute the concluding portion of a letter which we have received from Mr. W. Seth Gill, of Pentonville, on these subjects:-

"Let us (the general practitioners) not forget the old saying, 'Self-preservation is the first law of Nature.' Point ont to us, Sir, in what manner we ought to act, whether a petition to the Queen, Lords, or Commons, is the right course, and I have no doubt that 10,000 members will obey your summons, and rally round the standard you have so generously, resolutely, and fearlessly unfurled. We must and will prevent the snug and 'amicable arrangement' alluded to in your last LANCET. The thanks of the profession, Sir, and something beyond, are due to you, who have so incessantly laboured for the general welfare. We have 'cast our bread upon the waters' and through you we expect to 'find it, though after many days.'-I have the honour to be, Sir, yours obediently, Pentonville, May 29th, 1848. WilliaM SeTH Gill.

** Mr. Seth Gill will be gratified to perceive, by the letter immediately preceding his own, that the medical mon of Essex are up and stirring in the matter, and to see, by the announcement of Mr. Ottley, that a meeting of members of the College of Surgeons is about to take place in London. - ED. L.

\section{THE MEDICAL REGISTRATION BILL To the Editor of THe LanoET.}

SIR,-Accompanying this letter you will receive a petition for presentation to Parliament from the Port Philip Medical Association; and on behalf of that body $I$ have the honour to request, that you will have the kindness to present their petition to the House of Commons, and support its prayer.

I have also the honour to enclose to you the following extract from the minutes of the Association:-

"Resolved,-That the secretary be requested to convey to Mr. Wakley an expression of their grateful sense of his able and disinterested advocacy of the interests of the medical profession, and in particular, of their high opinion of the merits of the Medical Registration Bill, and of its adaptation to the wants of the profession, both in the mother country and in the colonies; also to enclose to Mr. Wakley a copy of the rules and regulations of the Association."

The copy of the rules you will find enclosed in the petition.-I have the honour to be, Sir, your most obedient servant,

Melbourne, Jan, 1848.

David E. Wilkie, M.D.

To the Honourable the Commons of Great Britain and Ireland, in Parliament assembled.

The petition of the Port Philip Medical Association, humbly showeth,-

That your petitioners are deeply convinced that the Medical Registration Bill, brought forward by the honourable member for Finsbury, would prove of much advantage to the members of the medical profession throughout the United Kingdom, and be of essential service to the public at large. And your petitioners humbly pray that the same privileges and protection as are therein proposed to be conferred on the members of the medical profession in the United Kingdom of Great Britain and Ireland be extended to the members of the medical profession in the Australian colonies, who form, in this part of her Majesty's dominions, a numerous and respectable body of her Majesty's subjects.

And your petitioners, as in duty bound, will ever pray.

Signed in name and by appointment of the Port Philip Medical Association, and sealed with the seal thereof, by authority of a meeting held in Melbourne on the seventh day of December, 1847. P. Cussen, M.D.

President Port Philip Medical Association.

\section{THE COLLEGE OF SURGEONS AND ITS CHARTER.} To the Editor of The LANCET.

Srr,-I was very much gratified to see in THE LANCET of May 27th, the very excellent letter of Mr. Foote, on the "College of Surgeons and its Charter." The subject is therein very justly stated; for it is quite certain that the many thousands of insulted and injured members of the College of Surgeons have been far more unjustly treated than the extralicentiates of the College of Physicians were about to be, much as the latter had cause to complain. At the time the infamous charter of 1843 was accepted by the council of the college, $I$, in common with a great number of the members, protested against being insulted and degraded by that odious retrospective law; which, to reiterate Mr. Foote's expression, must always be unjust; and I have many times since then felt 
degraded in belonging to a college, the members of which appeared quietly to succumb to the notorious injustice of the council, after the first burst of virtuous indignation was over. I once thought there was great reason to hope much from the association of members to which Mr. Drewry Ottley was secretary, but finding that association had but an ephemeral existence, I despaired of the many-headed monster, the commonalty of the college, being induced to act determinedly and perseveringly. Much confidence, also, was placed in the National Association and National Iustitute, but I fear that the ruling powers of those bodies have had their own interest too prominently in view, and have betrayed us. You may rely upon it, Mr. Editor, that a deep and stinging sense of injustice pervades the minds of the members generally, although they have lately appeared so apathetic. I trust, however, that a vast majority of them will, like myself, be very glad to hear that it is not yet too late to remedy the odious measure we complain of, and that they will respond, as one man, to your call; determined never to rest satisfied until they have obtained, either the total abrogation of the infamous charter of 1843 , or have been admitted fellows, and have been granted the privilege of voting in the election of the governing body of the college, in the way proposed by $\mathrm{Mr}$. Foote, and without the payment of any additional fees and they may rest assured their claims are so justly founded, that if placed properly before the legislature, or our justly popular sovereign, they will not be refused by either party. I perfectly agree in opinion with Mr. Foote, that the few members who have presented themselves for examination for the fellowship, and have paid the additional fees, would have no just cause to complain, as their position is not a creditable one-they may justly be regarded as traitors in our camp; for by thus weakly. succumbing to the council, they have strengthened them in their career of injustice. I think it is clear, from the evidence of Mr. Guthrie, that since the council acted so unjustly, they have not reposed on a bed of roses. Mr. Guthrie has undoubtedly shown himself friendly disposed towards us; but if, instead of weakly advising submission to Sir James Graham for fear of the consequence of opposing a measure which he knew to be unjust he had resolutely opposed it, he would have earnad for himself the everlasting gratitude of the members of the College of Surgeons. His motto, then, ought to have been, as it ought to be at all times with all of us-" Fiat justitia, ruat colum."

I am, Sir, your very obedient servant,

Lincolnshire, June, 1848.

M. Franks, M.R.C.S.

P.S.-I ought not to omit noticing the "Voice from the Crowd" of Liverpool surgeons. I trust many more such voices will arise.

\section{UNION AND NAVAL ASSISTANT-SURGEONS.}

$$
\text { To the Editor of THe LaNcEr. }
$$

SiR,-I read with interest whatever relates to the discussions, in Parliament, on the amendment of the medical section of the poor-law; and I am desirous to express my sympathy for the union-surgeons, both individually, as a member of the medical profession, and on the part of the naval assistantsurgeons, who, by their own humiliating position, have learned to feel for others in an oppressed condition. We have steadily endeavoured to raise ourselves from a station which is discreditable to the profession; but we feel our claims to better treatment stand not alone, when we regard the condition of the poor-law surgeons. We are anxious to co-operate with them in any measures that may be considered necessary to place the medical profession on a more respectable footing than, in some quarters, it holds at present, and chiefly those portions which are employed in the public services, and by the poor-law commissioners.

If, Sir, you can point out the way by which we may render assistance, we shall be still more deeply indebted to you for your kind advice; and we beg leave to repeat our thanks for the continued and energetic efforts you have made for us. I am, Sir, your obedient servant, ONE OF THE Assistant-Strggons R.N.

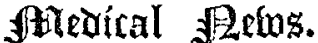

Rotal Coliege of Surgeons.-The following gentlemen, having undergone the necessary examinations for the diploma, were admitted members of the Collece at the meeting of the court of examiners, on the 2nd inst.-viz., Messrs. John
Wormald Dew, Halifax, Yorkshire; William Austin Gillow, Clifton, near Bristol; Joseph Adams, Collyhurst, Manchester; William Gillbee, Honourable East India Company's Service; Henry Thomas Parke, Thorpe-Latimer, Lincolnshire; and John Gunson, Limerick.

EFfects of LaUdanum upon Infants.-By the RegistrarGeneral's report for the week, it appears that an inquest was held on a child nine days old, which died after twelve hours illness, from the following cause:-The mother had been given castor oil and tinctura opii a month before, and told that it was a dose of castor oil only. She drank only half, and castor oil being afterwards prescribed for the child, she gave half a teaspoonful of the remainder to her, under the belief that it was only castor oil.

Filth aNd Feyer. - A medical practitioner makes, recently, a report to the Registrar of his district, that " the fatal cases of fever which have fallen under his observation have all occurred in houses exceedingly deficient in drainage and ventilation."

Royal Colugen of Physicrans.-The Harveian Oration annually delivered at this institution in commemoration of the illustrious discoverer of the circulation of the blood will be read by Dr. Francis Hawkins, on Saturday, the 24th instant.

Dr. Jepuson.--The foundation stone of the temple for the statue of this distinguished member of the profession has just been laid in the gardens at Leamington. This gentleman, though not professionally connected with the hospital, is an annual subscriber of one hundred guineas-a princely donation, which, in its magnificent liberality, it is believed is unequalled. We have just heard with great regret, that $\mathrm{Dr}$. Jephson is so ill as to occasion the greatest uneasiness to his numerous friends.

Foreigan Medical Prizes.-Our readers will no doubt feel an interest in the list of medical subjects for prizes which are offered this year in different parts of Europe. The languages in which the essays must be written is commonly either Latin, or that of the country where the prize is to be awarded. F'errara: The Medico-Chirurgical Academy offers a prize of $£ 20$ for the best monograph on chlorosis.Bruges: The Academy of Medicine will give a premium of \pm 12 for the best dissertation on the sanitary state of some district of West Flanders.-T'Toulouse: The Medical Society offers a premium for the best paper on Magnesia and its salts; wherein, in a therapeutical point of view, caustic magnesia is to be compared with the different salts containing organic acids. An extraordinary premium will likewise be given on the following question: "The actual advantages derivable from iodine injections in surgical practice." This question had not been sufficiently well answered last year. The papers are to be sent in before March, 1849. The value of each premium is \$12.-Bordeanx: The Societé de Médecine has announced a concours for the following questions: 1. Pellagra, considered principally in an ætiological point of view. 2. Are there any intermittent fevers which should be treated by other remedies than quinine?-Hamburg: The Medical Association offers a prize of twenty ducats, or about $£ 12$, for the best solution of the following question: "Are laryngismus stridulus, asthma laryngea, thymic asthma, the asthma of Kopp and of Millar, identical disenses ? or should they be distinguished from the state of suffocation caused by lesions of the recurrent nerves ?'-Lisbon: The Society of Medical Science has opened a concours for the three following questions: 1. Is phthisis as frequently met with amongst populations where intermittent fever is endemic as in those localities which are free from ague? 2. Should ethereal inhalations be used in surgical operations? 3. Fix the precise time of year when the flower of colchicum antumnale should be picked. Inquire whether the therapeutic action and the chemical composition of the active principles of the flower and bulb are identical. State whether the colchicum autumnale could, in practice, be replaced by the varieties multiflorum and bulbocoides. [It appears somewhat strange that the seeds of colchicum are not mentioned.-ED. L.]-Barcelona: The Academy of Medicine and Surgery has offered a gold medal, and the title of correspondent, to the author of the best paper on the following subjects: 1 . An exact and detailed description of some epidemic which has prevailed in Spain. 2. In what cases, and in which circumstances, vapour baths are likely to promote the cure of disease? 3. To what causes can be referred the occurrence of ague in Barcelona for the last few years, this disease having hitherto been hardly known to exist in that city? The papers may be written in Latin, French, English, Italian, or German, except in the first question, which should be in Spanish. 